Vol 11, Issue 1, 2018

\title{
ANTIHYPERTENSION STUDY OF ANREDERA CORDIFOLIA (TEN). V. STEENIS EXTRACT AND ITS FRACTIONS IN RATS THROUGH DEXAMETHASONE INDUCTION AND NITRIC OXIDE RELEASE
}

\author{
AFRILLIA NURYANTI GARMANA ${ }^{1 *}$, ELIN YULINAH SUKANDAR ${ }^{1}$, IRDA FIDRIANNY² \\ ${ }^{1}$ Department of Pharmacology - Clinical Pharmacy, School of Pharmacy, Bandung Institute of Technology, Indonesia. ${ }^{2}$ Department of \\ Pharmaceutical Biology, School of Pharmacy, Bandung Institute of Technology, Indonesia. Email: afrillia@fa.itb.ac.id
}

Received: 02 September 2017, Revised and Accepted: 15 October 2017

\section{ABSTRACT}

Objective: The aims of this study were to prove the antihypertensive effect of Anredera cordifolia (Madeira vine) in dexamethasone-induced hypertensive rat and to determine the release of nitric oxide (NO).

Methods: The rat's blood pressure was measured by CODA ${ }^{\circledR}$ tail-cuff blood pressure system. A hypertensive rat model was developed on day 7 after administration of dexamethasone injection $0.5 \mathrm{mg} / \mathrm{kg}$ body weight ( $\mathrm{bw}$ ). NO levels were measured by spectrophotometry at a wavelength of $546 \mathrm{~nm}$ after reacting the serum sample with Griess reagent.

Results: Ethanol extract of Madeira vine (EEMV), ethyl acetate fraction (EF), and water fraction (WF) could reduce systolic blood pressure at day 14 with a diastolic blood pressure (DBP) reduction of $26.8,34.1$, and $40.5 \mathrm{mmHg}$, respectively. DBP began to decrease from day 8 in the EEMV group with a DBP reduction of $24.1 \mathrm{mmHg}$. In the HF, EF, and WF groups, decreasing in DBP occurred on day 14 which were 22.0, 24.5, and 35.4 mmHg, respectively. NO level in rat serum was increased significantly at $90 \mathrm{~min}$ after administration of EEMV $100 \mathrm{mg} / \mathrm{kg}$ bw and WF $40.73 \mathrm{mg} / \mathrm{kg}$ bw. Increasing in NO levels due to EF with a dose of $1.66 \mathrm{mg} / \mathrm{kg}$ bw was not significantly different to control group.

Conclusion: Ethanol extract of $A$. cordifolia had the antihypertensive effect in dexamethasone-induced hypertensive rats, so does its WF and EF. The mechanism of ethanol extract of Madeira vine leaves and its WF most likely due to vasodilation effect through NO-pathway, whereas EF could have other mechanism(s) of action.

Keywords: Anredera cordifolia, Antihypertensive, Dexamethasone, Nitric oxide.

(C) 2018 The Authors. Published by Innovare Academic Sciences Pvt Ltd. This is an open access article under the CC BY license (http://creativecommons. org/licenses/by/4. 0/) DOI: http://dx.doi.org/10.22159/ajpcr.2018.v11i1.22312

\section{INTRODUCTION}

Hypertension is defined as blood pressure $\geq 140 / 90 \mathrm{mmHg}$. It affects millions of people, and the prevalence in adults aged 25 and over was around $32.5 \%$ in man and $29.3 \%$ in woman [1]. It is estimated that, by $2030,40.5 \%$ of the US population is projected to have some form of cardiovascular disease (CVD), including 37.3\% hypertension [2]. Hypertensive patients, which were related to CVD, need a medical attention [3]. Hypertension can be treated with pharmacological (using antihypertensive medicine) and non-pharmacological therapy (lifestyle modifications). If hypertension cannot be treated with only lifestyle modifications, antihypertensive medicine needs to be taken [4]. However, antihypertensive medicines have many side effects that can complicate the clinical problem. Diuretics may cause abnormalities of fluid and electrolyte balance. Side effects which are caused by angiotensin converting enzyme (ACE) inhibitors are cough, skin rash, hyperkalemia, kidney failure, and others. Calcium channel blockers may cause headache, flushing, dizziness, peripheral edema, constipation, and skin rash [3].

According to the World Health Organization survey, about $70-80 \%$ of the world populations rely on non-conventional medicine mainly of herbal sources in their primary health care [5]. It could be due to several advantages of herbal medicine such as: It is comparatively cheaper than modern remedies and treatments; complementary therapy is easily available; traditional medicines using herbs, vegetables, and fruits are free from any unwanted, undesired side effects; natural remedies, being general daily health supplements, not only help in curing the main disease but also soothe other body systems; and therefore, holistic remedies help in rejuvenating and revitalizing the human health [6]. However, the increasing popularity of herbal products as medications and food supplements has also raised concerns about their quality, safety, and efficacy (QSE) with uncertainty about their active compounds, their unsupervised use, as well as the legal responsibilities of practitioners. To ensure QSE of the herbal product, basic research programs should be focused on the toxicity and efficacy relationship for those potent or poisonous herbal substances [5]. One of the experiments to assess efficacy and safety of herbal is preclinical study in animal models. That study may provide an overview of efficacy, mechanism of action, effective dosage, or toxicity of herbal.

Madeira vine (Anredera cordifolia) traditionally used to reduce blood pressure. Preliminary studies of blood pressure lowering effect of Madeira vine (A. cordifolia) had been done [7]. That examinationshowed that the ethanol Madeira vine leaves extract had a potential antihypertensive effect. It could prevent heart rate increment which was induced by adrenaline. Sukandar et al. [8] showed vasodilation effect of $A$. cordifolia on rabbit aorta. Toxicity studies of $A$. cordifolia had been done and published in several journals [9-11], which showed that $A$. cordifolia quite safe to be used as herbal medicine even in pregnant women. Nevertheless, the antihypertensive effect of Anredera cordifolia have not been studied in chronic hypertensive animal model. One example of such animal model is dexamethasone-induced hypertensive rat, which had elevated blood pressure due to increased peripheral resistance [12,13]. On that model, elevated blood pressure can be antagonized by vasodilation due to increase of nitric oxide (NO) bioavailability, inhibition of $\alpha 1$ receptors, inhibition of ACE or AT1 receptor, or inhibition of calcium channels. This experiment intended to prove the antihypertensive effect of A. cordifolia in dexamethasone-induced hypertensive rat and elucidate the mechanism of its action. 


\section{METHODS}

\section{Preparation of ethanol extract and its fractions}

The leaves of $A$. cordifolia were collected from Lembang-Bandung and identified in Herbarium Bandungense, School of Life Science and Technology, Bandung Institute of Technology. Ethanol extract was prepared as described in the study of Garmana et al. Briefly, the Madeira vine leaves crude drug was extracted using $96 \%$ ethanol for $3 \mathrm{~h}$ at $80^{\circ} \mathrm{C}$ by reflux and repeated in 3 times. The ethanol extract was concentrated using a rotary evaporator (namely, ethanol extract of Madeira vine [EEMV]). The fractionation was carried out by liquid-liquid extraction method with n-hexane and ethyl acetate as solvents. A total of $100 \mathrm{~g}$ of extract was put in $500 \mathrm{ml}$ of boiling aquadest, then stirred and filtered while still hot. The filtrate was cooled, then put into separating funnel, and n-hexane was added with a volume ratio of 1:1. The mixture was shaken gently. The n-hexane fraction was separated, whereas the water fraction (WF) was reextracted using n-hexane up to 3 times. The water layer was then further extracted by adding ethyl acetate. The n-hexane (HF) and ethyl acetate fractions (EF) were collected and concentrated using a rotary evaporator. The WF was dried with freeze-dryer.

Phytochemical screening and determination of marker in fractions Phytochemical screening was conducted to determine the presence of saponin, quinone, flavonoid, tannin, alkaloid, and steroid/triterpenoid in extract and fractions. Thin layer chromatography (TLC) profile was determined using silica gel gel GF254 plate with toluene-ethyl acetate-formic acid (35:15:1) as mobile phase for n-hexane fraction; ethyl acetate-methanol-water (23:2:1) for ethyl acetate fraction.

\section{Experimental animal}

Male Wistar rats (200-300 g) were provided by School of Pharmacy, ITB. They were housed in clean and transparent polypropylene cages and maintained at $25-27^{\circ} \mathrm{C}$ and at a relative humidity of $55-75 \%$, under a 12-h light-dark cycle, and free access to food and water at all times. This study was approved by the Animal Research Ethics Committee - Bandung Institute of Technology (ethical approval No. 01/KEPHP-ITB/09-2016).

\section{Evaluation of antihypertensive effect}

In the evaluation of chronic antihypertensive effect of Madeira vine leaves extract, seven groups $(n=5)$ were used: Negative and positive control groups were given sodium carboxymethyl cellulose (Na CMC), EEMV group was given $100 \mathrm{mg} / \mathrm{kg}$ bw EEMV leaves, HF group was given $0.02 \mathrm{mg} / \mathrm{kg}$ body weight (bw) of n-hexane fraction, $\mathrm{EF}$ group was given $1.66 \mathrm{mg} / \mathrm{kg}$ bw of $\mathrm{EF}, \mathrm{WF}$ group was given $40.73 \mathrm{mg} / \mathrm{kg}$ bw of $\mathrm{WF}$, and standard group was given $0.45 \mathrm{mg} / \mathrm{kg}$ bw of amlodipine. Dexamethasone $0.5 \mathrm{mg} / \mathrm{kg}$ bw was given subcutaneously for 14 days. Extract, fractions, and amlodipine were administered on day 8-14. Blood pressure was measured by CODA $^{\circledR}$ tail-cuff blood pressure system on day 0 (before induction), day 7 (after induction), and days 8 , 10 , and 14 (1, 3, and 7 days after therapy) [14-16]. The obtained data were analyzed statistically using SPSS version 24 .

\section{Determination of serum NO levels}

The NO-involved vasodilation effect was studied in vivo by measuring the nitrite level in serum with Griess reagent. The rat blood was taken before and after administration of extract, fractions, or isosorbide dinitrate (ISDN) $1.8 \mathrm{mg} / \mathrm{kg}$ bw on min 0 (before drug administration), 30, 60, and 90. Blood samples were centrifuged at $10,000 \mathrm{rpm}$ for $10 \mathrm{~min}$. A total of $100 \mu \mathrm{l}$ serum was deproteined with the addition of $20 \mu \mathrm{lnSO} \mathrm{Zn}_{4} 6 \%$, then centrifuged again. The supernatant was reacted with cadmium for $15 \mathrm{~min}$. A total of $50 \mu \mathrm{l}$ aliquots was put in a microwell-plate and 50 $\mu \mathrm{l}$ of Griess reagents were added, and then incubated for $30 \mathrm{~min}$. The absorbance was measured by Microwell-plate reader at a wavelength of $546 \mathrm{~nm}$ [17-19]. It was proportional to NO level in the serum samples. The obtained data were analyzed statistically using SPSS version 24 .

\section{RESULTS}

Phytochemical screening of the EEMV leaves showed that it contained flavonoid, phenol, and steroid/triterpenoid. The fractionation yields
$0.02 \%, 1.66 \%$, and $40.73 \%$, respectively, of n-hexane, ethyl acetate, and WF. Phytochemical screening of the fractions was presented on Table 1. The TLC profile showed that ursolic acid could be a marker compound in HF, apigetrin (apigenin-7-0-glycoside) could be a compound marker in $\mathrm{EF}$, while in WF marker compound was a flavonoid compound.

Administration of extract, fractions, and amlodipine showed an effect on rat blood pressure. In general, it can be seen that the extract and all of fractions can lower blood pressure in hypertensive animal models (Fig. 1). Ethanol extract, WF, and EF could decrease systolic blood pressure (SBP) significantly on day 14 (day 7 after therapy). EEMV, $\mathrm{EF}$, and $\mathrm{WF}$ reduced SBP by $26.8,34.1$, and $40.5 \mathrm{mmHg}$, respectively. Amlodipine decreases SBP gradually. It reduced SBP significantly from day 10 (day 3 after amlodipine administration). After 7 days administration of amlodipine, SBP reduced by $34 \mathrm{mmHg}$.

Similar results were observed in diastolic blood pressure (DBP) (Fig. 2). The extract, fractions, and amlodipine expressed significantly decrease the DBP on day 14 (day 7 after therapy). In the extract group, the DBP decreased significantly from the first day of extract administration (day 8). After 7 days of EEMV administration, DBP decreased by $24.1 \mathrm{mmHg}$. HF, EF, and WF reduced DBP by 22.0, 24.5, and $35.4 \mathrm{mmHg}$, respectively. Amlodipine reduced DBP by $29.1 \mathrm{mmHg}$.

Fig. 3 denoted experimental results of the determination of NO levels in rat serum. In general, it could be seen that the administration of ISDN, EEMV, ethyl acetate, and WF could increase NO levels in rat serum. Administration of ISDN caused a gradual increase of NO levels from the min 30. A significant increase occurred on min 60 and then slightly decreased on min 90 . In the extract and fractions groups, increasing in NO levels started on min 30. A significant increase in the extract group occurs on min 60 and 90 , while in the WF group, NO levels increased significantly on min 90 . In the EF group, the highest increase of NO levels occurred on min 90, but it was not significant compared to the negative control group which also gave a slight increase of NO levels.

\section{DISCUSSION}

Arterial blood pressure is strongly influenced by blood flow (cardiac output) and resistance to blood flow (peripheral resistance). Cardiac output is a function of stroke volume, heart rate, and venous capacitance, whereas total peripheral resistance reflects vascular resistance, blood viscosity, and turbulence $[4,20]$. The effects of ethanol extract of Madeira vine leaves extract on heart rate and cardiac output have been investigated. Madeira vine leaves extract could prevent heart rate increment induced by adrenaline. It also showed diuretic and natriuretic activity [7]. In this study, its effect on vascular resistance was studied.

Dexamethasone administration may cause functional impairment of vascular smooth muscle cells, thus increasing peripheral resistance of the blood vessels. In general, it can occur as a result of two reasons. The first reason: Increasing in sensitivity and reactivity of blood vessels to vasoconstrictors [12]. It is probably due to increased expression of angiotensinogen [21], increased expression of angiotensin II receptor

Table 1: Phytochemical screening of n-hexane, ethyl acetate, and water fraction

\begin{tabular}{llll}
\hline Group & HF & EF & water fraction \\
\hline Alkaloid & + & + & - \\
Flavonoid & + & + & + \\
Saponin & - & - & - \\
Quinone & - & + & - \\
Tannin & - & - & - \\
Phenol & + & + & + \\
Steroid/triterpenoid & + & + & - \\
\hline
\end{tabular}

+: Detected, -: Not detected, HF: n-hexane fraction 


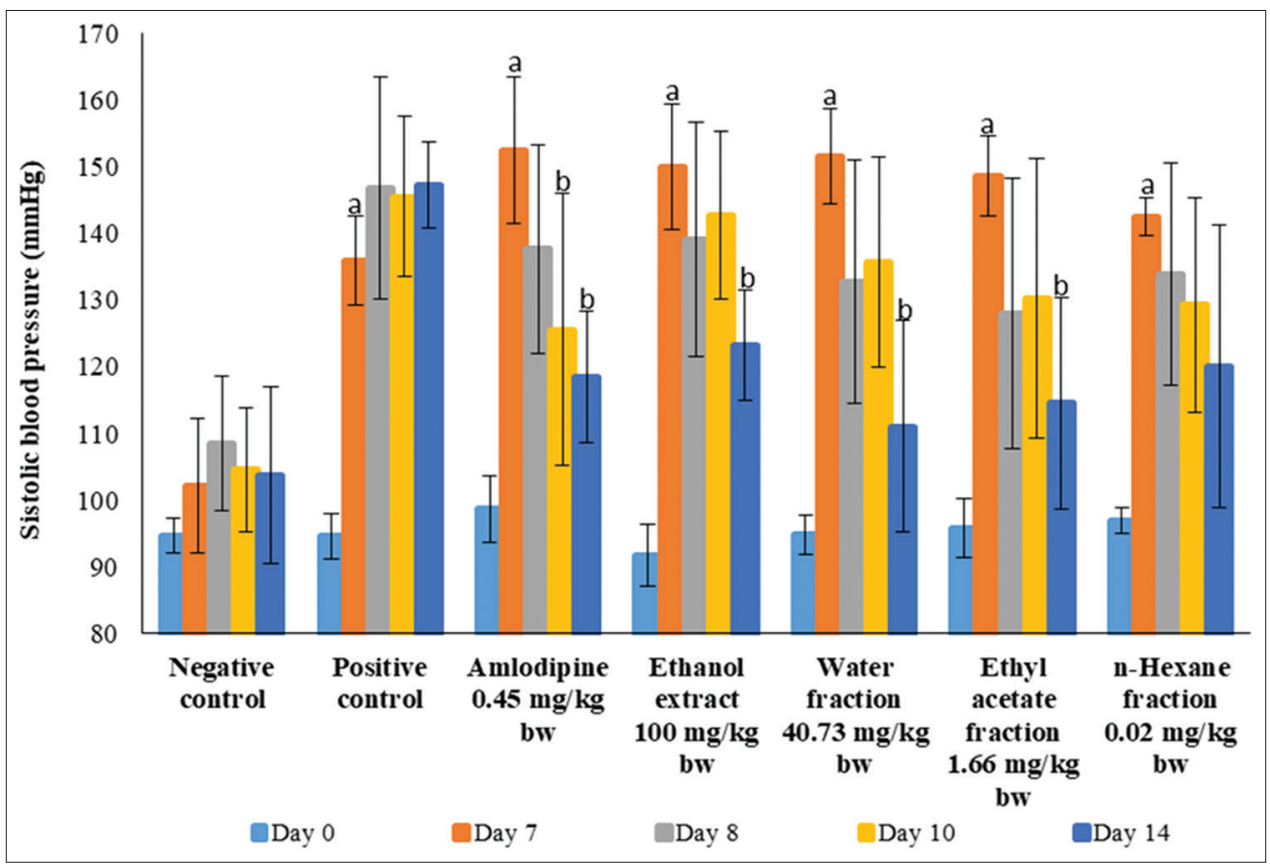

Fig. 1: Systolic blood pressure before and after administration of Madeira vine leaves extract and its fractions. Data are expressed as

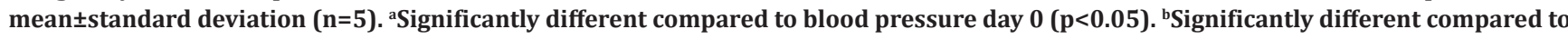
blood pressure day $7(p<0.05)$

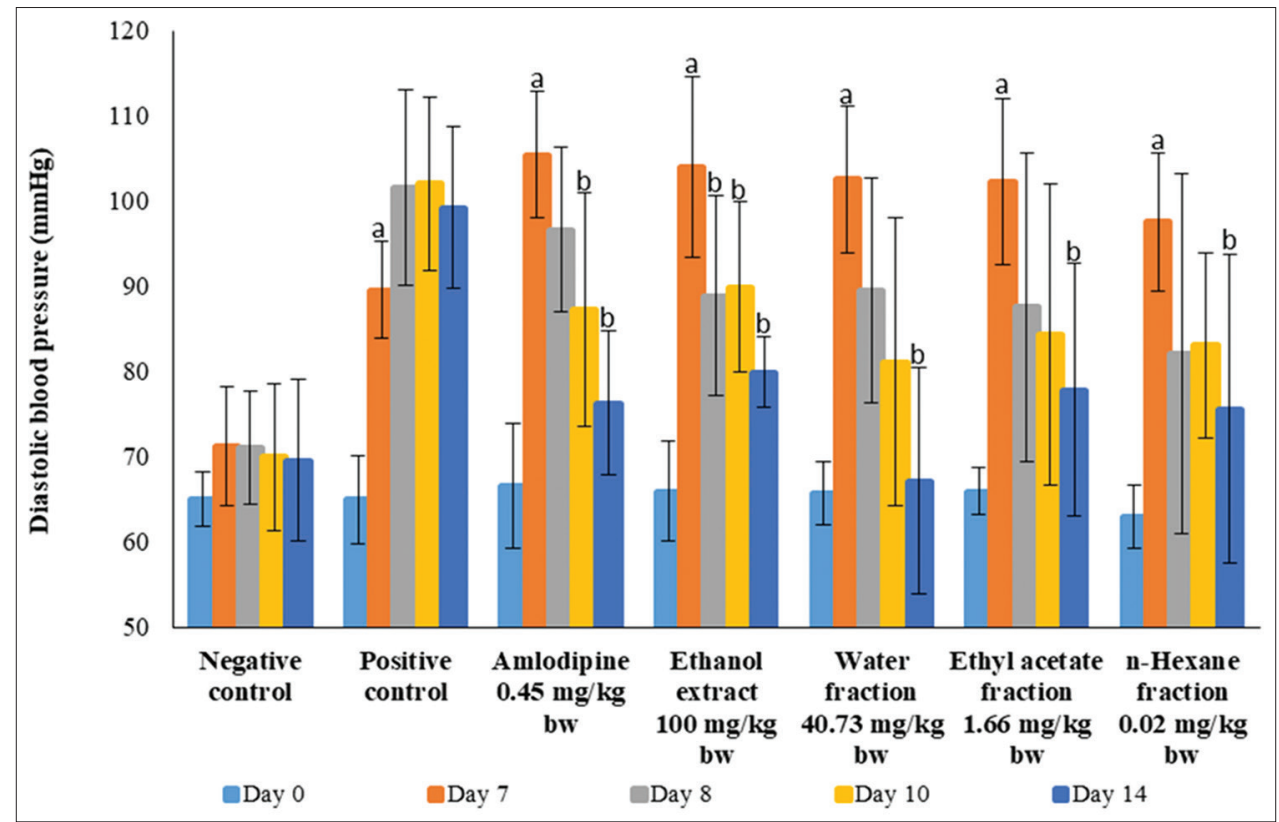

Fig. 2: Diastolic blood pressure before and after administration of Madeira vine leaves extract and its fractions. Data are expressed as

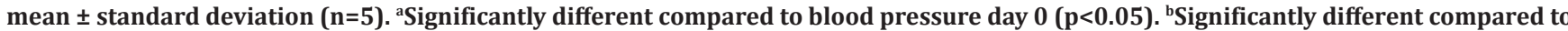
blood pressure day $7(\mathbf{p}<0.05)$

gene [22], or increased expression of $\alpha 1$ receptor genes in blood vessels $[23,24]$. The second: Decreasing in bioavailability of vasodilators such as prostaglandins and NO. It might be caused by decreasing synthesis [12,22] or increasing inactivation of prostaglandins and NO [12,13] result in oxidative stress in the blood vessels. Oxidative stress and NO deficiency will lead to vasoconstriction, increased peripheral resistance, and increased blood pressure both SBP (Fig. 1) and DBP (Fig. 2).

The increasing in SBP and DBP after giving dexamethasone $0.5 \mathrm{mg} / \mathrm{kg}$ bw for 7 days showed that induction was successful and hypertensive animal model had been established. Amlodipine can be used as standard as it has antihypertensive and antioxidant effects that can inhibit many of the oxidative stress-dependent mechanisms involved in Ang II-mediated cardiovascular injury [25].

From the experimental results, it can be assumed that the Madeira vine leaves extract and its fractions caused vasodilation and could decrease peripheral resistance, and hence, they can antagonize the effects of dexamethasone. Vasodilation effects can be achieved through several ways, including: (a) Increased levels of NO, (b) inhibition of $\alpha 1$ receptors in blood vessels, (c) inhibition of ACE or AT1 receptor in blood vessels, and (d) inhibition of calcium channels. 


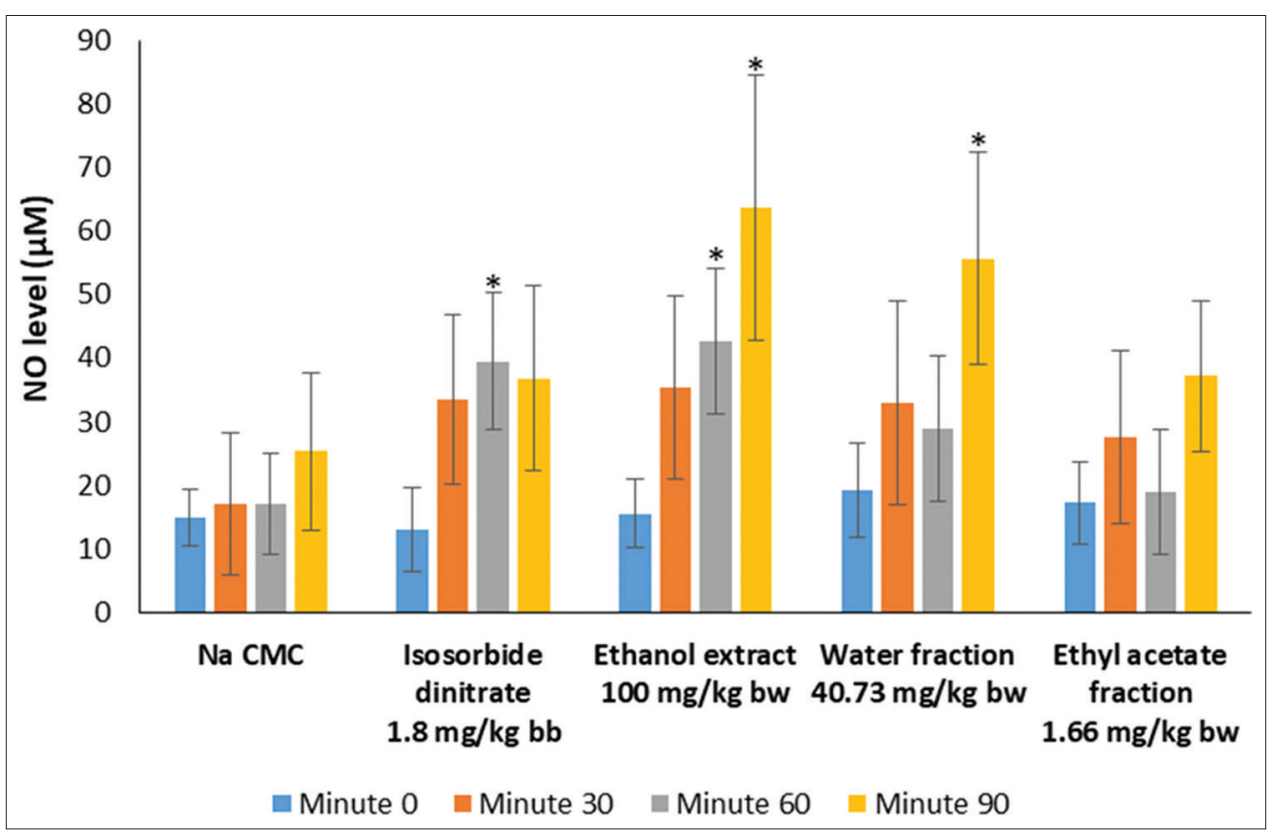

Fig. 3: Nitric oxide levels before and after administration of Madeira vine leaves extract and its fractions. Data are expressed as mean \pm standard deviation $(n=5)$. *Significantly different compared to Na CMC group $(p<0.05)$

Decreasing in peripheral resistance can also be attributed to the antioxidant effect of EEMV. The antioxidant properties of the extract could reduce superoxide formed when oxidative stress occurs. The antihypertensive actions may also caused by the complex pharmacological mechanism from various kinds of constituents [26]. The result of experiment on dexamethasone-induced hypertensive rats showed that the most effective were ethyl acetate and WF. Therefore, the experiment continued on both fractions by measuring the NO levels in the rat serum.

NO is released from the endothelial. Before the structure is elucidated, it is known as endothelium-derived relaxing factor. In the blood vessel wall, $\mathrm{NO}$ is produced mainly from L-arginine by the enzyme endothelial NO synthase (eNOS), but it can also be released non-enzymatically from S-nitrosothiols or nitrate/nitrite. NO diffuses into the smooth muscle, then stimulates guanylyl cyclase, and induces cGMP formation. Furthermore, cGMP will activate the protein kinase $\mathrm{G}$ which promotes calcium absorption into the sarcoplasmic reticulum until the calcium content in the cytosol decreases and evoke relaxation of smooth muscle of blood vessels [27].

Determination of NO levels can be associated with the vasodilatory effect of a substance. The higher levels of NO in the blood denoted greater vasodilation effect. NO has a short half-life and undergoes metabolism in the body to nitrate and nitrite $[28,29]$. Therefore, the determination of NO levels can be done indirectly by measuring the levels of metabolites. Nitrite concentration can be determined colorimetrically using the Griess reaction. The nitrate component present in the biological sample should be converted first into nitrite by adding a reductor, for example, cadmium. The nitrite component in the sample will react with sulfanilamide in an acidic condition forming diazonium ion which is then coupled with N-(1-napthyl) ethylenediamine to form a chromophoric azo product that absorbs strongly at $540 \mathrm{~nm}$ [19].

NO level determination showed that the NO level profile of extract and WF was different from ISDN (Fig. 3). The WF has a slower onset than ISDN. However, EEMV and WF may have a longer duration. It can be an advantage over its use since it reduces the frequency of drug administration. The EF showed a slight increase in NO levels. However, this fraction showed a hypotensive effect on dexamethasone-induced hypertensive animals. Based on the result, it can be suggested that there are other mechanisms in the antihypertensive effect of $\mathrm{EF}$ in addition to the effect of NO levels. Other possible mechanisms include calcium channel blocker, alpha receptor blocker, or inhibition of ACE.

Phytochemical screening showed that extract and all of fractions contained flavonoid and phenolic compound. Phenolic compounds widely distributed and the most secondary metabolite found in plants. It can act as an antioxidant since it can scavenge free radicals [30]. Phenolic compounds included phenolic acid, anthocyanin, and flavonoid [31]. Flavonoid is the biggest group of phenols found in higher plants and is effective antioxidant in plants and animals $[32,33]$. Flavonoid as a food supplement could decrease the risk of cancer, cardiovascular, and neurodegenerative disease [34]. Based on the chromatogram profile of Madeira vine leaves fraction, marker compound of the EF was apigenin-7-0-glycoside, whereas marker compound of WF was flavonoid compound. Flavonoids were known to have various pharmacological activities including antihypertensive effects. Its effect can be achieved through vasodilation or antioxidant properties of flavonoids [35]. Flavonoids scavenge the free radicals, so it can reduce superoxide $\left(\mathrm{O}_{2}{ }^{-}\right)$concentration and prevent the formation of peroxynitrite ( $\mathrm{ONOO}^{-}$). In addition, flavonoids also modulate the bioavailability of $\mathrm{NO}$ at the cellular level by increasing the expression of the enzyme NO synthase (NOS) [36,37]. Flavonoids could be a compound that plays a role in their antihypertensive effect.

\section{CONCLUSION}

An EEMV ( A. cordifolia) had antihypertensive effects in dexamethasoneinduced animal model so does its WF and EF. The mechanism of Madeira vine leaves extract and its WF most likely due to vasodilation effect through NO-pathway, whereas EF could have another mechanism (s) of action. The antihypertensive effect of the extract and fractions could be due to its flavonoids content. Madeira vine leaves can be exploited as a source of natural antihypertensive agents.

\section{REFERENCES}

1. WHO. World Health Statistics 2012. Geneva: WHO Press; 2012. p. 111.

2. Heidenreich PA, Trogdon JG, Khavjou OA, Butler J, Dracup K, Ezekowitz MD, et al. Forecasting the future of cardiovascular disease in the United States. Circulation 2011;123(8):933-44.

3. Brunton LL, Chabner BA, Knollmann MB, editors. Goodman and Gilman's the Pharmacological Basis of Therapeutics. $12^{\text {th }}$ ed. New York: The McGraw-Hill Companies, Inc.; 2011. 
4. Saseen JJ, MacLaughlin EJ. Hypertension. In: Dipiro JT, Talbert RL, Yee GC, Matzke GR, Wells BG, Posey LM, editors. Pharmacotherapy: A Pathophysiologic Approach. 9 ${ }^{\text {th }}$ ed. New York: McGraw-Hill Education; 2014. p. 156-203.

5. Chan K. Some aspects of toxic contaminants in herbal medicines. Chemosphere 2003;52:1361-71.

6. Singh P, Mishra A, Singh P, Goswami S, Singh A, Tiwari KD. Hypertension and herbal plant for its treatment: A review. Indian J Res Pharm Biotechnol 2015;3(5):358-66.

7. Garmana AN, Sukandar EY, Fidrianny I. Preliminary study of blood pressure lowering effect of Anredera cordifolia (Ten.) steenis) on Wistar rats. Int J Pharmacogn Phytochem Res 2016;8(2):300-4.

8. Sukandar EY, Ridwan A, Sukmawan YP. Vasodilatation effect of ethanolic extract of Anredera cordifolia, Sonchus arvensis L, and ursolic acid on isolated rabbit aortic and frog heart. Int J Pharm Pharm Sci 2016;8(2):145-9.

9. Kaaffah S, Kurniwati F, Kusuma AM, Djalil AD. The effect of ethanol extract from binahong leaves (Anredera cordifolia (Ten.) steenis) on histopathology changes in female Wistar rats. In: Proceeding of The $1^{\text {st }}$ University of Muhammadiyah Purwokerto-Pharmacy International Conference; 2015. p. 18-26.

10. Salasanti CD, Sukandar EY, Fidrianny I. Acute and sub chronic toxicity study of ethanol extract of Anredera cordifolia (Ten.) v. steenis leaves. Int J Pharm Pharm Sci 2014;6(5):348-52.

11. Sukandar EY, Kurniati NF, Fitria V. Evaluation of teratogenicity effects of ethanolic extracts of binahong leaves (Anredera cordifolia (Ten) steenis) in Wistar rat. Int J Pharm Pharm Sci 2014;6(11):422-6.

12. Ong SL, Zhang Y, Whitworth JA. Mechanisms of dexamethasoneinduced hypertension. Curr Hypertens Rev 2009;5:61-74.

13. Nagata K, Murohara T, Miyachui M, Ohtake M, Tsuboi K, Ohtake M, et al. Glucocorticoid-induced hypertension and cardiac injury: Effects on mineralocorticoid and glucocorticoid receptor antagonism. Nagoya J Med Sci 2013;75:81-92.

14. Safaeian L, Zabolian H. Antioxidant effects of bovine lactoferrin on dexamethasone-induced hypertension in rat. ISRN Pharmacology 2014;1-6.

15. Wallwork CJ, Parks DA, Schmid-Schönbein GW. Xanthine oxidase activity in the dexamethasone-induced hypertensive rat. Microvasc Res 2003;66(1):30-7.

16. Handa M, Kondo K, Suzuki H, Saruta T. Dexamethasone hypertension in rats: Role of prostaglandins and pressor sensitivity to norepinephrine. Hypertension 1984;6:236-41.

17. Ozdestan O, Uren A. Development of a cost-effective method for nitrate and nitrite determination in leafy plants and nitrate and nitrite contents of some green leafy vegetables grown in the Aegean region of Turkey. J Agric Food Chem 2010(9);58(9):5235-40.

18. Amalia L, Sukandar EY, Roesli R, Sigit JI. The effect of ethanol extract of kucai (Allium schoenoprasum L.) bulbs on serum nitric oxide level in male wistar rats. Int J Pharm 2008;4:487-91.

19. Bryan NS, Grisham MB. Methods to detect nitric oxide and its metabolites in biological samples. Free Radic Biol Med 2007;43(5):645-57.

20. Martini FH, Nath JL, Bartholomew EF. Fundamentals of Anatomy and Physiology. $10^{\text {th }}$ ed. San Francisco: Pearson Education, Inc.; 2015.

21. Pandey VG, Jain S, Rana A, Puri N, Arudra SK, Mopidevi B, et al. Dexamethasone promotes hypertension by allele-specific regulation of the human angiotensinogen gene. J Biol Chem 2015;290:5749-58.

22. Saruta T. Mechanism of glucocorticoid-induced hypertension. Hypertension Res 1996;19(1):1-8.

23. Sakaue M, Hoffman BB. Glucocorticoids induce transcription and expression of the alpha 1B adrenergic receptor gene in DTT1 MF-2 smooth muscle cells. J Clin Invest 1991;88(2):385-9.

24. Haigh RM, Jones CT. Effect of glucocorticoids on alpha 1-adrenergic receptor binding in rat vascular smooth muscle. J Mol Endocrinol 1990;5(1):41-8.

25. Zhou MS, Jaimes EA, Raij L. Inhibition of oxidative stress and improvement of endothelial function by amlodipine in angiotensin II-infused rats. Am J Hypertens 2004;17:167-71.

26. Adnyana IK, Setiawan F, Insanu M. From ethnopharmacology to clinical study of orthosiphon stamineus benth. Int J Pharm Pharm Sci 2013;5(3):66-73.

27. Zhao Y, Vanhoutte PM, Leung SW. Vascular nitric oxide: Beyond eNOS. J Pharmacol Sci 2015;129:83-94.

28. Lundberg JO, Weitzberg E, Gladwin MT. The nitrate-nitrite-nitric oxide pathway in physiology and therapeutics. Nat Rev Drug Discov 2008;7:156-67.

29. Kelm M. Nitric oxide metabolism and breakdown. Biochim Biophys Acta 1999;1411:273-89.

30. Sharifi N, Souri E, Ziai SA, Amin G, Amanlou M. Discovery of new angiotensin converting enzyme (ACE) inhibitors from medicinal plants to treat hypertension using an in vitro assay. DARU $\mathrm{J}$ 2013;21(71):1-8.

31. Babbar N, Oberoi HS, Sandhu SK, Bhargav VK. Influence of different solvents in extraction of phenolic compounds from vegetable residues and their evaluation as natural sources of antioxidants. J Food Sci Technol 2014;51(10):2568-75

32. Balasuriya BN, Rupasinghe HV. Plant flavonoids as angiotensin converting enzyme inhibitors in regulation of hypertension. Funct Foods Health Dis 2011;1(5):172-88.

33. Croft KD. The chemistry and biological effects of flavonoids and phenolic acids. Ann N Y Acad Sci 1998;854:435-42.

34. Stevenson DE, Hurst RD. Polyphenolic phytochemicals-just antioxidants or much more? Cell Mol Life Sci 2007;64(22):2900-16.

35. Mladenka P, Zatloukalová L, Filipský T, Hrdina R. Cardiovascular effects of flavonoids are not caused only by direct antioxidant activity. Free Radic Biol Med 2010;49(6):963-75.

36. Duarte J, Francisco V, Perez-Vizcaino F. Modulation of nitric oxide by flavonoids. Food Funct 2014;5:1653-68.

37. Sudano I, Flammer AJ, Roas S, Enseleit F, Ruschitzka F, Corti R, et al. Cocoa, blood pressure, and vascular function. Curr Hypertens Rep 2012;14(4):279-84. 